\title{
Girl Child in India- Present Plight to Future Bright
}

\author{
Bhag Singh Karnawat ${ }^{1 *}$, Khushboo Agarwal $^{2}$ and Kirti Dave ${ }^{\mathbf{3}}$ \\ ${ }^{1}$ Senior Professor and Unit Head, Department of Pediatrics, JLN Medical College, Ajmer, India \\ ${ }^{2}$ Senior Resident, Department of Pediatrics, JLN Medical College, Ajmer, India \\ ${ }_{3}^{3} J u n i o r$ Resident, Department of Pediatrics, JLN Medical College, Ajmer, India \\ *Corresponding Author: Bhag Singh Karnawat, Senior Professor and Unit Head, Department of Pediatrics JLN Medical College, Ajmer, \\ India.
}

Received: October 11, 2019; Published: November 05, 2019

DOI: $10.31080 /$ ASPE.2019.02.0178

\begin{abstract}
Census 2011 reflected a declining trend in the Child Sex Ratio (CSR) between 0-6 years, reaching an all time nadir of 918 girls to 1000 boys. CSR reflects both, prenatal as well as post birth discrimination against girls. Easy availability of diagnostic tool has been contributory in increasing sex selective elimination leading to low Sex Ratio at Birth (SRB). SRB for period 2008-10 was 908 as against the internationally observed normal SRB of 952 . Strong socio-cultural biases, preference for sons and discrimination towards daughters have accentuated the problem. A host of laws have been enacted from time to time to save the girl child in India. PCPNDT (Pre-conception and Pre-natal Diagnostic Techniques) Act 1994 (Amended in 2016) has come as a boon to curb the menace of female foeticide. A number of girl child welfare programs and schemes have been initiated to uplift the quality of their life, latest being " The Beti Bachao, Beti Padhao (BBBP) Abhiyan "launched in 2018. Some of the important laws/ programs are comprehensively reviewed herewith which would be instrumental in improving the life of a girl child in India- both quantitatively as well as qualitatively.

Keywords: Girl Child; Female Foeticide, Child Sex Ratio (CSR); PCPNDT Act; 'The Beti Bachao, Beti Padhao (BBBP) Abhiyan
\end{abstract}

\section{Introduction}

It is a sad paradox that when we, on one hand, venerate our country as Bharat Mata and worship Durga, on the other hand, carry out reprehensible practices like female foeticide, girl child sex trafficking, dowry- deaths, bride- burning, etc. Girls are treated as a burden- "paraya dhan". A girl child is increasingly being excluded from life itself.

\section{Skewed child sex ratio}

Census-2011 reflected a declining trend in the Child Sex Ratio (CSR) between 0-6 years. An all-time low of 918 girls to 1000 boys was startling. The decline in the CSR is a major indicator of women disempowerment. CSR reflects both, pre-birth discrimination manifested through gender biased sex selection-as well as post-birth discrimination against girls [1]. Though the CSR is influenced by number of factors such as under registration of girls, differential infant and child mortality, strong socio-cultural biases as mentioned above, it is in large measure determined by Sex Ratio at Birth (SRB). SRB is defined as number of girls born per 1000 boys. The SRB for the period 2008-10 was 908 (Figure 1) as against the internationally observed normal SRB of 952; clearly pointing out to lesser number of girls being born than the boys in India. Easy availability and affordability of diagnostic tools has been contributory in increasing Sex Selective Elimination (SSE) leading to low SRB. Strong socio-cultural biases leading to preference for sons and discrimination towards daughters have accentuated the problem.

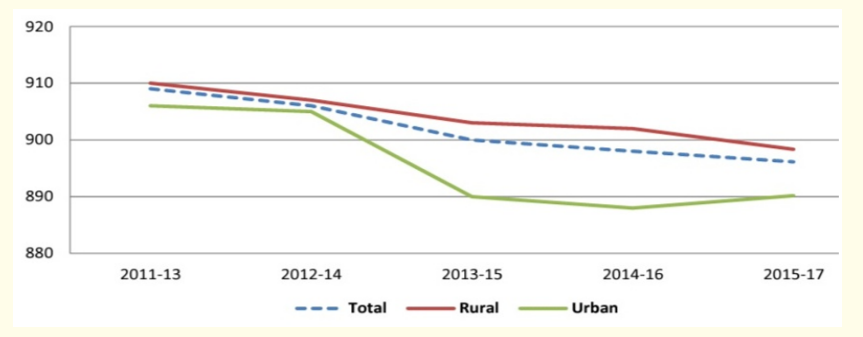

Figure 1: Sex ratio at Birth.

\section{Social consequences}

The abnormal sex ratio leads to a lot of unpleasant long-term consequences. There is increased violence against women- one hears of repugnant incidences of infants being raped. Young men cannot find brides. The frustrated youth either turns to commercial sex workers and are exposed to HIV and other STDs or such persons can turn to antisocial or violent crimes and lured into antinational militant activities. 
Female education $[2,3]$

According to global statistics, women make up more than twothird of the world's 796 million illiterate people. Furthermore, just 39 percent of rural girls attend secondary level schools. This is far fewer than rural boys ( 45 percent), urban girls (59 percent) and urban boys ( 60 percent).

According to census of 2011, India's female literacy rate is 65.46 percent, significantly lower than the world average of 79.7 percent. The Right to Education (RtE) Act, introduced in 2009 making elementary education free and compulsory, has been a shot in the arm for many in our country. Nevertheless, statistics reveal the dismal gap between states - while states like Kerala paint a rosy picture of women's education in India with 92.07 percent female literacy, relatively backward states such as Bihar with 51.5 percent female literacy rate highlight the importance of sustained campaign in favour of women's education in India.

Female education in other developing countries is also in dire state. In Pakistan a half-kilometre increase in the distance to school will decrease girls' enrolment by 20 percent. In Cambodia, 48 percent of rural women are illiterate compared to 14 percent of rural men.

Improving female education is an essential prerequisite for women empowerment and family well-being. A recent study has shown that maternal education significantly influences health seeking behavior of mothers e.g. immunization status of their children [4].

\section{Medical problems}

Generally a girl child in India is discriminated and is less priviledged. Their health and medical issues are not addressed as promptly and adequately as their male counterparts. This saga of problems begins well from the birth of a girl child and runs to elder age till she herself becomes a mother. This deplorable life cycle of a girl in developing world is vividly depicted in Figure 2 [5].

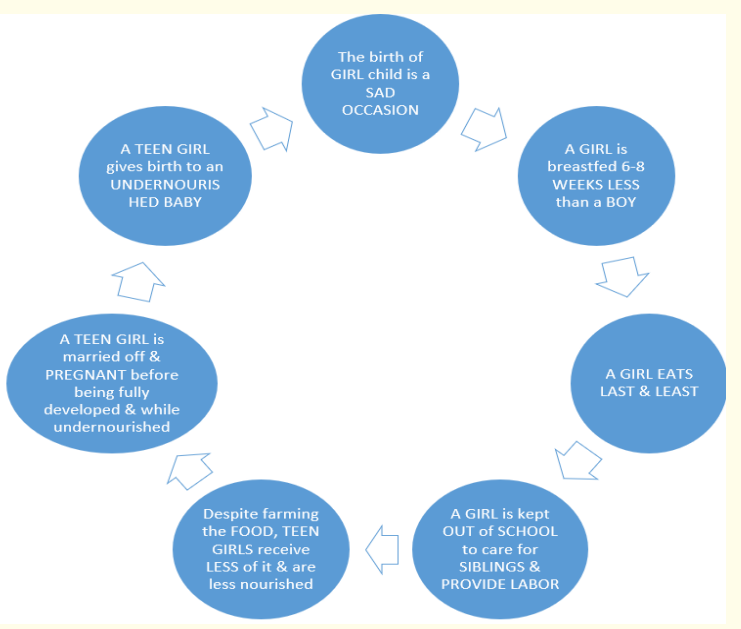

Figure 2: The life of a girl child in the developing world.
A girl child is not even given full benefit of free preventive and curative health services provided by the government. According to NFHS-3 data immunization rates for 2 year old girls was $41.7 \%$ as compared to $45.3 \%$ for boys. Obviously, this lower protection leads to increased morbidity/ mortality in a girl child due to vaccine preventable diseases.

According to UNICEF- 2011, 47\% of teenage girls in India aged 15-19 years old are underweight which is highest in world. More than half of these girls (56\%) are anemic which increases the risk of maternal, foetal and neonatal mortality significantly [6]. Malnutrition and anemia in a girl leads to poor physical growth and mental development which is further aggravated with start of menses during adolescence. Use of unhygienic menstrual material makes her susceptible to urogenital infection.

A study from South Asia suggests gendered effects of siblings on child malnutrition in India, Bangladesh and Nepal. Having brothers heighten girl's risk for acute malnutrition whereas having multiple sisters increased girl's risk for chronic malnutrition; whereas boy's malnutrition is less affected by gender of siblings [7]. In India roughly $43 \%$ of girls are married and $22 \%$ give birth before they turn 18 , due to this every year 6000 teenage mothers loose their lives. An average of 239000 excess death of girls per year under age of 5 years or 2.4 million in a decade occurs in India. This excess female child death is found in $90 \%$ of the districts in the country [8]. Statistics show that female infant mortality rate (IMR) is higher than the male IMR (Figure 3).

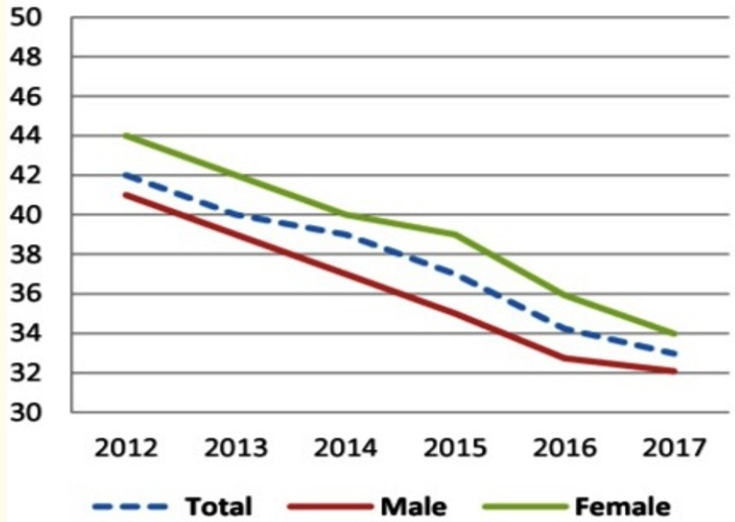

Figure 3: Infant Mortality Rate.

\section{Laws and schemes to save the girl child}

Coordinated efforts are needed to ensure survival, protection, optimal upbringing and education of girl child to help realize her full potential. Various laws and schemes having direct or indirect beneficial impact on life of girl child are enlisted below: 
Laws having direct impact

1. PC.P.N.D.T. Act 1994 (Amended in 2003) (Pre-conception and Pre-natal Diagnostic Test) Act.

2. The Prohibitions of Child Marriage Act 2006 (Sharda Act 1930).

\section{Laws indirectly beneficial}

1. Medical Termination of Pregnancy Act (1931)

2. Special Marriage Act (1954)

3. Hindu Adoption and Maintenance Act (1956)

4. Maternity Benefit Act (1961)

5. Dowry Prohibition Act (1961)

6. Indian Divorce Act (1969)

7. Equal Remuneration Act (1976)

8. Indecent Representation of Women Act (1986)

9. Child Labour Act (1986)

10. National Commission for Women Act (1990)

11. Protection of Children from Sexual Offences (POSCO) Act, 2012

12. Sexual Harassment of Women at Workplace Act (2013)

13. The Muslim Women (Protection of Rights on Marriage) Act, 2019

Girl child welfare programmes/schemes $[9,10]$

1. The Beti Bachao, Beti Padhao Abhiyan (2018) [11]

2. Pradhan Mantri Matru Vandana Yojana (Previously Indra Gandhi Matritva Sahyog Yojna ) 2017 [12].

3. "Daughters Are Precious" Campaign (2016)

4. Mukhyamantri Rajshree Yojna (2016)

5. Pradhan Mantri Surakshit Matritva Abhiyan (2016)

6. UJJAWALA (2016) [13]

7. SABLA Rajiv Gandhi Scheme for Empowerment of Adolescent Girls (2011) [14]

8. Nutrition Programme for Adolescent Girl (2009-10)

9. Kishori Shakti Yojana (2007) [15]

Some of the most important laws/ programmes are described in detail underneath :-

Pre-conception and pre-natal diagnostic techniques [16] (Prohibition of Sex Selection) Act, 1994 (PCPNDT)

One of the major causes of steep decline in the CSR is female foeticide/infanticide and discrimination between girl and boy child. Under this scheme, the district authorities monitor villages and ensure that there is no sex determination test conducted in any health care establishment. There are awareness campaigns where parents and families are educated not to go for the test and embrace girl child. Intervention is focussed to enforce existing Legislations and Acts, especially to strengthen the implementation of Pre Conception and Pre-Natal Diagnostic Techniques (Prohibition of Sex Selection) Act, 1994 (PCPNDT Act) with stringent punishments for violations of the law. The role of medical professionals in this regard has not been the most laudatory. There may have been a few black sheep who conducted pre-natal sex determination and female foeticide, but the rest of the doctors should have put a stop to this. Regulatory bodies like MCI and IMA should have been more proactive in weeding out these nasty elements from the profession.

Unique features adopted by Rajasthan Government in implementing PCPNDT are highlighted below:

1. 104 and 108 helpline for complaints

- Anyone can file complaint against sex determination/ selection on 104 and 108 Toll free services.

- It is very easy to access through website Hamaribeti. nic.in

2. Impact software

- The website address is http://pcpndt.raj.nic.in

- The system is designed and developed by the National Informatics Centre-Rajasthan

- More than 1554 + sonography centres are registered online.

- More than one crore Form-F have been submitted online till date (since launch date).

- More than 8000 online Form-F are being submitted by centres on daily basis.- 30 lakh

- $\quad$ sonography p.a.

- More than 2666 + Tracking devices have been installed.

3. Mukhbir network and the decoy operations

- Under the scheme, state government has declared award of Rs. 2,50,000/- to the "Mukhbir" for giving authentic information of sex selection; out of which $40 \%$ of the amount is given to informant, other $40 \%$ of the award amount is given to pregnant lady and rest $20 \%$ is given to the attendant of the pregnant lady. Till 2017 total 83 decoy operations were conducted in the state.

4. Regular inspections by appropriate authorities at state/ district/sub division

5. Separate courts for hearing such cases in all districts

6. Active tracker on sonography machines

7. GPS on new machines

8. Establishment of PBI (PCPNDT Bureau of Investigation)

\section{The Beti Bachao, Beti Padhao (BBBP) Abhiyan}

Societal changes must come about through a churning in society. If that is not forthcoming, the government must nudge in these changes by either judicial activism, legislative or executive initiative, or through journalistic intervention of an independent Press and TV. This campaign was launched by Prime Minister Narendra Modi on 8th March 2018 (i.e. World Women Day) from Rajasthan to address the decline in CSR through a mass campaign across the 
country, and focussed intervention and multi- pronged action in 100 gender critical districts. There are two main objectives of the scheme - preventing female foeticide and promoting education of girl child. Nationwide campaigns are conducted to induce mindset change in people through training, raising awareness and importance of educating girl child. This joint initiative was taken by Ministry of Women and Child Development, Ministry of Human Resource and Development And Ministry of Health and Family Welfare. Recently this programme along with Nutrition Mission was expanded to all districts of India.

\section{Protection of girl child}

The scheme ensures well being, protection and security of girl child after her birth. With options like ' Sukanya Samriddhi', parents or legal guardian can open a small savings account for girls. A small contribution is needed for 14 years and the next 7 years, one will be able to earn interest on it, thus the account matures at 21 years.

\section{Educating female child}

One of the major discrimination in India is female education. The scheme spreads awareness and campaigns to educate female girl child so that they grow up to become self empowered. The district level officials educate people with importance of girl education. Free elementary education is provided to girls of under privileged families. The aim is to spread $100 \%$ education and literacy amongst females. There is positive impact after the implementation of this scheme, as there is increase in CSR. More families welcome the birth of a girl child happily- the stigma no longer exists. There is increase in education levels of girls after implementation of BBBP scheme.

\section{Mukhyamantri Rajshree Yojna [17]}

Congratulatory message signed by the Chief Minister of Rajasthan is given to every mother who comes to government institution for delivery and delivers a girl child. From birth of a girl child to her passing 12th standard education from a government school, a total sum of Rs 50,000 is given in installments.

Recent success stories of some female medical professionals

- Dr. Soumya Swaminathan, a pediatrician, became first Indian to be appointed as Deputy Director General of WHO (2017).

- Dr.Shiralee Runwal, the "Golden Girl of Gwalior" has secured first rank among girls (overall second) in NEET PG 2018. She has been appointed as brand ambassador of "Daughters are precious campaign" in Madhya Pradesh.

- Dr. Manushi Chillar a medical student from Haryana, has been crowned Miss World 2017.
What more needs to be done?

Other suggested initiatives include:

- A more stringent Anti-Dowry Act to deter dowry seekers.

- Preventing child marriages through compulsory registration of marriages.

- Celebrating the birth of the girl child in a grand way.

- Laying emphasis on the education of the girl child for their empowerment.

- Involving Zila Panchayats in implementing and monitoring BBBP.

- Offering economic incentives as a motivation.

- Ensuring safety of women in public transport system.

- Establishing easily accessible women safety cells.

- Conducting campaigns on sensitization towards women and girl child.

- $\quad$ Setting up cybercrime cells to prevent stalking and trolling on social media.

- Instituting awards for role models, parents and other categories.

\section{Conclusion}

In comparison to their male counterparts, the girl child in India is largely marginalized and discriminated, not only in socioeconomic and educational aspects, but also in medical and health related issues. Thanks to implementation of different legal and legislative actions as well as launching of various girl child welfare and public awareness programmes by the government; this present plight of female child is slowly but surely going to change into bright future. To ensure this transformation the society also need to change its mind set. To quote.

"We've begun to raise daughters more like sons, but few have the courage to raise our sons more like our daughters".

Gloria Steinem

\section{Bibliography}

1. Govt of India, Ministry of Health and Family Welfare, New Delhi. Health and Family Welfare Statistics in India 2017, Statistics Division (2017).

2. http://www.unwomen.org>in-focus

3. http://women-S.net/womens-education-in-india

4. Agarwal K., et al. "Study of immunization status of under-five children in relation to various demographic variables of their mothers". International Journal of Contemporary Pediatrics 6 (2019): 1964-1970. 
5. The life of a girl child in the developing world (2019).

6. Girl-Child in India Most Susceptible to Malnutrition. State of the World's Children Report 2011 UNICEF (2011).

7. Raj A., et al. "Gendered effects of siblings on child malnutrition in South Asia; A cross sectional analysis of Demography and Health Surveys from Bangladesh, India and Nepal". Maternal Child Health Journal 19 (2015): 217-226.

8. Guilmoto CZ., et al. "Excess under- 5 female mortality across India: spatial analysis using 2011 census data". The Lancet Global Health 6 (2018).

9. Vyas S., et al. "Adolescent Health". In: IAPSM's Textbook of Community Medicine. Ed. AM Kadri. First Edition. New Delhi: Jaypee Brothers Medical Publishers (2019): 757-765.

10. Banerjee B and Banerjee R. "Health Policies and Programs in India”. In: IAPSM's Textbook of Community Medicine. Ed. AM Kadri. First Edition. New Delhi: Jaypee Brothers Medical Publishers (2019): 1068-1136.

11. Govt. of India, Ministry of Health and Family Welfare, New Delhi. Annual Report of Health and Family Welfare 2017-18 (2018).

12. Pradhan Mantri Matru Vandana Yojana, Scheme implementation guidelines. Ministry of Women and Child Development, GIO, New Delhi (2017).

13. Park K. "Preventive Medicine in Obstetrics Pediatrics and Geriatrics". In: Park's text book of Preventive and Social Medicine. 25th Edition. Jabalpur: M/s Bhanot publishers (2019): 645-650.

14. Department of Women and Child Development (GOI) (2010).

15. Ministry of Women and Child Development (GOI). Kishori Shakti Yojana- A new initiative. Guidelines for implementation of adolescent girls scheme as a component under centrally sponsored ICDS (general) scheme (2000).

16. http://pcpndt.raj.nic.in

17. www.rajswasthya.nic.in

Volume 2 Issue 12 December 2019

(C) All rights are reserved by Bhag Singh Karnawat., et al. 